\title{
Educational pathways and decisions - Comparing the returns of investment in Germany and Canada
}

\author{
Silvia Annen, Michael Tiemann \\ Federal Institute for Vocational Education and Training, Germany
}

\begin{abstract}
The presented results derive from a project which focuses on the competition between vocational and higher education. Within the project qualification and skill utilization of the respective educational programmes shall be evaluated with regard to occupational status and positions as well as income. The research concept contains curricula and vacancies analyses, case studies and a quantitative survey. The theoretical background is formed by the signaling and screening approach as well as the segmentation theory.

This paper analyses data from the qualification and career survey of 2011/2012 and focuses on employees' income. From an individual perspective the monetary outcomes of persons with equivalent qualifications are compared. Equivalence of qualifications refers to the German National Qualification Framework (GQF). To find comparable occupational positions the national classification of occupations which includes information on qualificational requirements is used. The results are compared with respective data from Canada.
\end{abstract}

\section{Introduction}

Germany expects deep changes in the educational system and on the labour market due to the introduction of three year, vocationally qualifying bachelor programmes. Two central arguments constitute the possible substitution or even erosion of apprenticeships and firm-based trainings: due to changes in recruitment patterns of firms, vocationally trained persons could be competing with academically trained bachelor graduates for the same positions and students leaving school with a higher degree allowing them to go to a university could increasingly flow into bachelor programmes instead of taking up an apprenticeship. In Germany the implementation of the new Bachelor programmes offers young people the opportunity to gain an academic qualification in a comparable duration to established apprenticeships (leaving aside the possibility of shortening VET programmes for high-performance trainees). But in comparison to those apprenticeships an academic qualification promises higher prestige and higher wage classification as well as giving access to a broader set of follow-up programmes $[1 ; 2 ; 3]$.

Further trainings regulated by public law can be linked to three levels of the GQF. The first level ("Fachberater") is linked to level 5, master craftsmen and comparable vocational degrees ("Meister" and "Fachwirte") are linked to level 6 and the third group ("Betriebswirte") is linked to level 7. This means they are equivalent to bachelor (level 6) and master (level 7) degrees. Changing recruiting strategies of firms to favour academically trained graduates would cut traditional vocational career paths and thus the attractiveness of VET as a whole. Commercial and theory oriented occupations are expected to experience high competition between vocationally and academically (especially in bachelor programmes) trained graduates, unlike industrial and skilled manual occupations [4].

Up to now, several surveys among companies have been conducted to learn more about the acceptance of, experiences with and partly (first steps) of bachelor graduates' career paths. Results differ and show relatively high acceptance and positive employment prospects of bachelor graduates $[5 ; 6 ; 7]$.

Kopatz/Pilz give a short overview of the existing research on earnings corresponding to educational qualifications [8: 312ff]: Overall, and with just a few exceptions, a recent OECD study shows that individual returns to investment in education for graduates exceed those of individuals with post-secondary education below tertiary level. In Canada (as well as on OECD average) tertiary education yields on average $39,24 \%$ higher $(57,17$ $\%$ higher) earnings compared to post-secondary education. Further studies also show that the returns to investment in education from post-secondary education are lower than those on tertiary level for a range of qualifications [9]. Different studies prove that the returns to investment in education for Canadian graduates are above-average [10]. Stark (2007) analyses the returns to investment in education within various academic areas. The results illustrate an even larger range of returns when specific courses of study are analysed than former research already showed - concrete between $7.6 \%$ and $25.0 \%$. 
Based on the above Kopatz/Pilz (2015) analyse the income differences of vocational and academic qualified employees in Canada. They state that the ,academic drift" is seen as causing problems, for example leading to higher shares of formally mismatched employees, which seems largely to refer to "over-education" [8: 310]. For comparing tertiary to post-secondary education they examine the "return to investments in education" (so called "shortcut-method") defined as the "benefit gained from the period spent in education" [8: 311f] including gross costs and benefits (e.g. university fees).

\section{Theoretical background}

The analysis of the career paths of employees in commercial occupations tries to combine the perspectives of individuals and firms. The individual decision to take up a bachelor program versus an apprenticeship is based on the information they have about possible future labour market outcomes of the respective programs. The firms on their part recruit the persons of whom they think they match best with the tasks demanded by them on the job. Regarding this their information about the contents and the outcomes of the respective educational programs as well as the expected productivity of the graduates are of interest.

In order to combine these perspectives analytically, the project refers to the signaling and screening theory as well as the segmentation theory. The signaling theory developed by Spence treats the problem of reduction of information asymmetries on markets by using signals [11: $355 \mathrm{ff}$.]. The core idea is that the better informed stakeholder acts first to give the less informed stakeholder a signal pointing to a not directly recognizable characteristic.

These theoretical reflections are transferable to the labour market, what Spence does in his analysis. In this context employers are not sufficiently informed about the skills of their job applicants. Their characteristics become apparent over time, why the hiring decision can be characterized as an investment decision under uncertainty [11: 356ff.]. The information bases for the employers' decisions are the individuals' CVs, credentials and letters of reference. As they can't observe to which extent the applicants meet their requirements, they have to build assumptions based on the available information.

If the applicants can change or influence a characteristic those can be signals. This is the reason why Spence differentiates between signals and indices, whereas the latter cannot be changed or influenced [11: 357]. Age and gender are examples for indices. These indices do not contain information about unobservable characteristics. Hence applicants have the opportunity to signalize potential employers their productivity and their suitability for the respective job or function by documenting their educational achievement (i.e. degrees and certificates). In doing so the so called signaling costs are caused for the applicants in terms of time and money [11: 358]. As long as the expected earnings in terms of higher wages are high enough applicants accept these costs.

The signaling costs have to be negatively correlated to the productivity to be signalized, because otherwise the signal does not distract productive from less productive applicants as the acquirement of the signal causes the same costs for both groups [11: 358]. A certain characteristic can be a signal for certain types of jobs. Figure 1 illustrates the information feedback process within the signaling model.

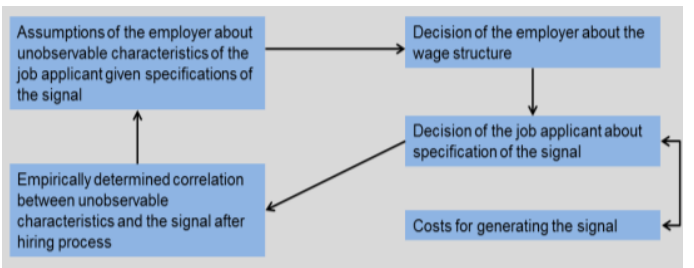

Figure 1. Information feedback process in the signaling model [11: 359]

The following results refer to the signaling theory as we have a closer look at the monetary outcomes of different (academic and vocational) educational attainments of employees in certain occupations respectively occupational fields. In our calculations we furthermore consider the duration of the different educational programs. So from the individuals' perspective we take into account two important aspects for their decision regarding their investment into the signal.

Besides the signaling and screening theory the project refers to the approach, which Sengenberger developed to structure the labour market analytically and to reduce its complexity in reality [11, p. 209ff.]. He differentiates between three ideal types of labour markets: the unstructured, the occupational and the in-company labour market. He characterizes them as follows: On the unstructured labour market there is no mutual bond between the employer and the employee. Employees rather own an undirected mobility and wages are used as steering mechanism. The occupational labour market in contrast is characterized by a mutual bond between supplier and demander of labour to a certain occupation. While applicants depend on certain job, which requires a certain qualification, they don't depend on a certain employer. Employers also do not depend on certain applicants, but on certain certified qualifications. This labour market is adjusted by changing the employer and through coordinated change or modification of the qualification configuration of the applicants or the qualification requirements of the employers. On incompany labour markets the employees and the 
employers are characterized by a mutual bond. A quantitative or qualitative balance of supply and demand of workload conducts the adjustment.

Based on this differentiation there are two options to structure labour markets. One could use the three types to develop a one-dimensional model or one could combine the organizational form of the partial labour market with the quality of the employment to reach a two-dimensional model. The latter implements the dimension of quality into the model [12, p. 209f], which Figure 2 illustrates.

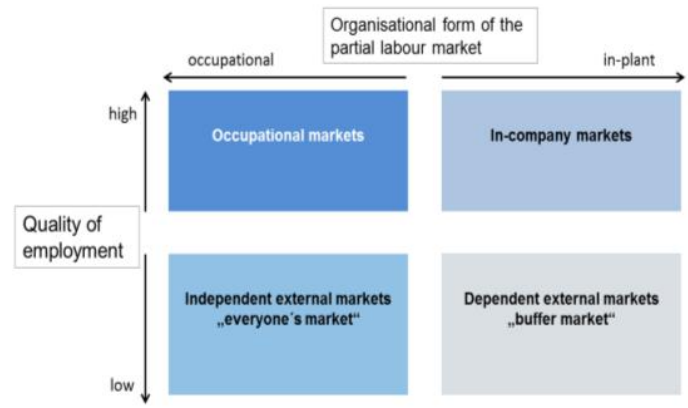

Figure 2. Sengenberger's model of partial labour markets. [12: 211]

In his model Sengenberger differentiates the unstructured labour market into an independent and a dependent segment. While within the independent segment employees and jobs are not related to other segments, this is the case for the dependent segment. As they buffer certain risks and costs for the other segments, those markets are called buffer markets. In any case employments of a different quality have a complementary relationship: the quality of employment in one segment improves to the same extend as the quality of employment in another segment declines [12, p. 211]. The reallocation of quality of employment through the distribution of jobs into "good" and "bad" corresponds to the concept of a dual labour market model [13].

This model is used as theoretical basis for the analysis of the employment in the commerce sector. Within the following analyses the focus lies on both part labour markets where the quality of employment is high and qualified work is traded respectively matched either internal or external of the company.

\section{Methodology, data sets and operationalization}

In the project a combination of qualitative and quantitative methods is used. We conduct document analysis for examining contents of corresponding vocational and academic qualifications of the respective curricula to assess the actual comparability of vocational and academic trainings preparing for occupational positions linked to the same level of the GQF. Vacancies will be analysed to identify requirements and expectations of companies regarding the respective positions and activities. The data hold information on the positions and jobs advertised, on the requirements the firms set and also on the occupational qualification required - plus (if applicable) alternative occupational qualifications. Recruitment strategies of enterprises and will be examined by means of case studies and a company survey. With this we look at how firms deal with the uncertainties and incomplete information about educational programs and the actual capabilities of applicants. Finally a follow-up survey to the 2017/18 Employment Survey will be conducted to deliver insights into the usability of vocational and academic qualifications on the job market - in particular from the individual point of view.

The following results are based on an analysis of data from the BIBB/BAuA Employment Survey 2012. This is a representative computer-assisted telephone interview (CATI) survey of 20,036 persons in core-employment. The mean interview time was about 40 minutes. Respondents gave selfassessed information on different aspects of their working conditions, the tasks to be performed, fields of knowledge they have to be proficient in, different qualification and situational requirements and also their qualification paths with up to five completed programs. Being in core-employment means these persons have to hold a paid job of at least 10 hours a week which is not an apprenticeship and they have to be older than 15 . For more information see [14]. The data are weighted with a structural weight with the German Microcensus 2012 as reference structure. Due to its large sample size the data allows for detailed analyses in large enough sub-populations as well as comparisons between different groups.

In order to identify occupation-specific returns to investment, we use occupational main fields (OMF). These are based on occupational fields [15], which structure occupations form the German national classification of occupations into groups of occupations with similar tasks-profiles. These are aggregated to main fields according to the predominant tasks performed in the occupational fields.

Using the shortcut-method [16] to denote the private return to investment in education [8: 314f] one can compute gross income differentials with the employment data, restricting the analyses to persons with their highest education being either academic or vocational training. Four levels are differentiated: Academic training (including all academic education except for bachelor's degrees), bachelors' degrees, further education and initial vocational education and training (IVET). The following formula will be used to compare income gain due to academic training to an average income in this training period for someone with a vocational training: $r_{\mathrm{i}}=\left(\overline{Y_{\mathrm{Ia}}}-\overline{Y_{\mathrm{ID}}}\right) /\left(d_{\mathrm{ia}}^{s} * \overline{Y_{\mathrm{ID}}}\right)$, with $r_{\mathbb{1}}:=$ return to investment in education in 
occupation $\mathrm{i} ; \overline{Y_{\text {I }}}:=$ average gross income in occupation i for those with academic training; $\overline{Y_{I V}}:=$ average gross income in occupation $i$ for those with vocational training and $d_{i a}^{s}:=$ (estimated) average duration of academic training for occupation $i$.

For the Canadian case current data calculating and comparing return to investment of qualifications is provided by Kopatz/Pilz [8: 315f]. They chose six occupations based on the accessibility of data as well as trying to include professions from the "middle of society" instead of classic academic professions that attract comparatively high earnings. The chosen training occupations are plumbers, electricians, and oil and gas well drillers, while the three academic occupations are librarians, social workers, and family, marriage and other related counsellors. Kopatz/Pilz use most recent available data from 2005 collected by Statistics Canada. These are Census Income Data, based on a $20 \%$ sample of the Canadian population.

They calculate national return to investment in education and compare gross income, where the Canadian statistics data do not differentiate between earnings from employment and earnings from selfemployment. To calculate the return to investment the period spent in education is a further key component. Referring to Bayard and Greenlee [17] the average duration of a Bachelor's degree course in Canada is 3.3 years and a subsequent Master's course takes 2.2 additional years on average. In comparison, for example, the duration of vocational training courses is on average four years for plumbers and electricians and three years for the various oil and gas industry occupations [8: 316f].

Although Kopatz and Pilz [8] use the short-cut method, they state that it is inferior to other methods like a net present value calculation. Also, Psacharopoulos and $\mathrm{Ng}$ [16], despite introducing the short-cut method, do not use it due to the fact that it is not accounting for age effects. However, data restrictions limit our possibilities here to make use of another method. One aspect to solve is the collection of data about the individual costs for education. We are planning on assessing these in a follow-up study to the coming-up BIBB/BAuA Employment Survey. Comparing to other research (e.g. Tamborini et al. [18], comparing life-time earnings for US qualifications or Jeong et al. [19] for returns to experience) our findings using the short-cut method are sensible and do give a reasonable idea on the relation of returns to investment for different educational pathways.

\section{Returns to investment for education in Germany and Canada}

In the German case the analyses (see Table 1) show that academic qualified employees on average achieve higher incomes than employees qualified in further educational programmes. This is particularly the case in OMF 9 (Legal, management and economic science occupations) with nearly 4 percent higher returns of investment (line 1). The question is whether bachelor graduates can also realise such a positive return to investment for their academic qualifications. But if instead of all academics only bachelor graduates are compared to persons who have completed further education (line two) the positive effects clearly decrease or even turn negative. For OMF 9 an employee with a bachelor's degree would yield $3.22 \%$ lower returns to investment than someone who completed a further education.

Table 1. Returns of investment in education in Germany

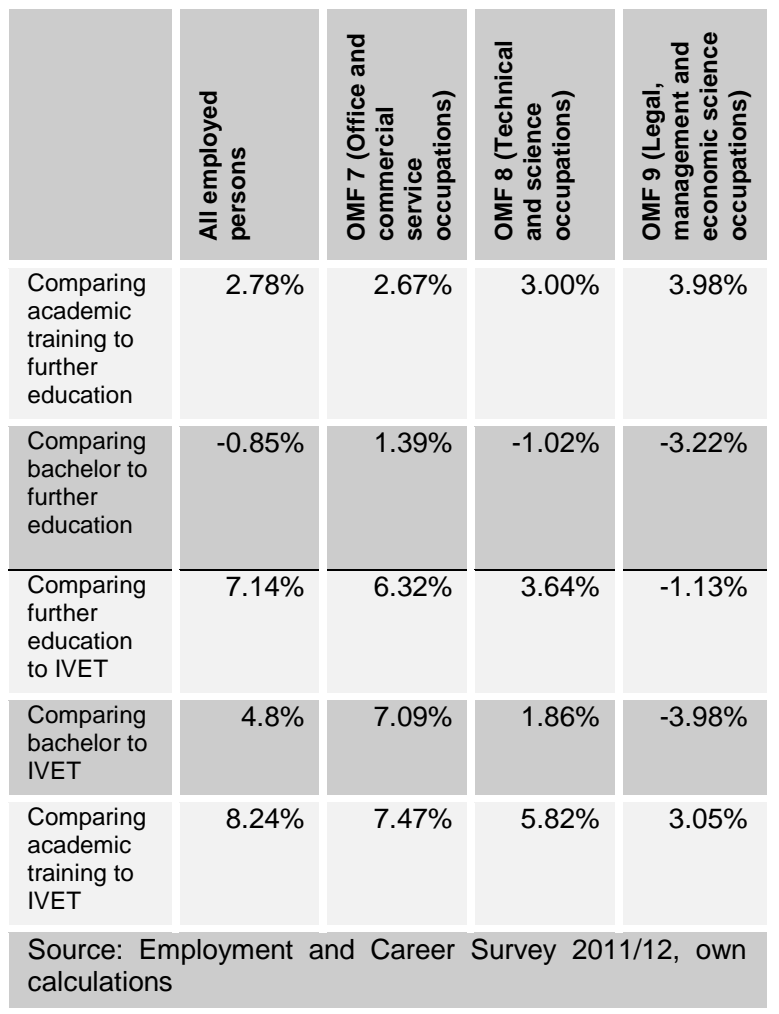

The results are even clearer when using apprenticeships as a standard of comparison. Compared to employees whose highest qualification is an apprenticeship academic qualified as well as further trained employees achieve higher incomes. It is noticeable that the income advantage of employees who hold a bachelor's degree (line four) is considerably smaller than that of further trained and academic qualified employees. Taking apprenticeships as standard of comparison interesting differences between different occupational fields also become apparent. Here the negative effects of further training and bachelor's degrees in the OMF 9 are especially mentionable, although they can possibly be explained by regulations in this field of work. For technical and science occupations there are no comparable regulations and the pattern clearly 
favours academic training over initial vocational education and training (with $5.82 \%$ higher returns) and also favours further training over IVET $(+3.64$ $\%)$; but, most intriguing: the returns with a bachelor's degree $(+1.86 \%)$ are even lower than those for a further training.

Overall results for Germany implicate that academic education as well as further education lead to higher incomes, which means a positive return on investment in post-secondary education above apprenticeship level. This is the case over all employed persons and most OMFs. But the results also show that this slightly positive effect is related to the occupational field as well as the concrete post-secondary educational programme. Overall and in most OMFs (except for OMF 7, Office and commercial service occupations) employees who hold a bachelor's degree take the lowest monetary advantage out of their qualification. The returns to investment between further training and bachelors' degrees being comparably high in the field of commercial occupations supports the thesis of a higher competition due to new educational pathways here.

Kopatz/Pilz (2015) calculate returns to investment in education by comparing median earnings for a given occupation with earnings for those in the same occupation with a lower level of qualification [8: 316]. To explain the following figure they use the following example: about $87 \%$ of all librarians have a Master's degree and earn 58,281 CAD a year, while the ones without a degree earn 39,056 CAD a year. Relating this differential to the duration of training leads to the return to investment in education for each level of qualification expressed as a percentage.

Using OECD data Kopatz/Pilz (2015) compare the earnings of skilled and unskilled workers, which shows that in 2005, workers without a vocational training earned on average $78 \%$ of what workers with vocational qualifications were earning [8: 317] (admitting that the differential between earnings from employment and self-employment may be substantial). They relate this fact to the identical figures for the return for plumbers and electricians. Overall and after rounding up, the return to investment in education for the considered academic courses ranges from $5.2 \%$ to $9.5 \%$, while for plumbers, electricians and oil and gas well drillers, it ranges from $7.1 \%$ to $9.4 \%$. These results prove that vocational qualifications can lead to comparable or even higher returns to investment in education than academic qualifications.
Table 2. Returns of investment in education in Canada [2: 316]

\begin{tabular}{|c|c|c|c|}
\hline Occupation & $\begin{array}{l}\text { Duration } \\
\text { of training }\end{array}$ & $\begin{array}{l}\text { Annual } \\
\text { income }\end{array}$ & $\begin{array}{l}\text { Return to } \\
\text { investment in } \\
\text { education }\end{array}$ \\
\hline $\begin{array}{l}\text { Libarians } \\
\text { (degree) }\end{array}$ & 5.2 years & $\$ 58,281$ & $9,47 \%$ \\
\hline $\begin{array}{l}\text { Family, } \\
\text { marriage and } \\
\text { other related } \\
\text { counsellors } \\
\text { (degree) }\end{array}$ & 4.1 years & $\$ 48,242$ & $5,19 \%$ \\
\hline $\begin{array}{l}\text { Social workers } \\
\text { (degree) }\end{array}$ & 4.1 years & $\$ 54,799$ & $7,38 \%$ \\
\hline $\begin{array}{l}\text { Plumbers } \\
\text { (vocational } \\
\text { training, VT) }\end{array}$ & 4.0 years & $\$ 45,984$ & $7,05 \%$ \\
\hline Electricians (VT) & 4.0 years & $\$ 48,484$ & $7.05 \%$ \\
\hline $\begin{array}{l}\text { Oil and gas well } \\
\text { drillers (VT) }\end{array}$ & 3.0 years & $\$ 65,994$ & $9,40 \%$ \\
\hline
\end{tabular}

\section{Comparative reflection of results}

For the Canadian case Kopatz/Pilz consider the key determining factors of the Canadian education and training system to evaluate their findings. Although during the last 20 years the numbers of young people registering for and (half of them) also completing an apprenticeship grew, the share of apprentices is still low in comparison to academically qualified people [20]. This situation is completely different in Germany, where so far the highest share of a cohort enters the vocational training system and gains a respective qualification instead of an academic qualification. However in Germany there is a continuing trend towards academisation, which is shown in the vocational training report 2015. Graduates from general schools tend to choose an academic instead of a vocational qualification more often [21]. Adjusted calculations of the beginners in the educational sectors show that the number of new training contracts in the German vocational training system (ca. 490,000) is only marginally higher than the number of first-year students (ca. 460,000) [22].

Kopatz/Pilz rise the fundamental question, why higher-performing, young people decide to achieve an academic qualification rather than a vocational qualification, ignoring that a range of vocational occupations offer excellent earnings opportunities in comparison. Focusing on the economics of education besides earnings they focus on the following elements, which might also affect educational decisions: job security and career prospects, satisfaction with training and employment, and social status/prestige, admitting that those four aspects are not always entirely discrete and may also be interdependent [8: 319f]. But discussing job security and career prospects as well as satisfaction with training and employment considering the available research results does not provide an explanation why vocational training has such a poor reputation and low status in Canada. In Germany we see a highly institutionalised nexus 
between education system and labour market with occupational qualifications (especially VET trainings in the dual system). This is often seen as a reason for low youth unemployment and might explain the high reputation of VET in Germany.

Looking at the remaining aspect, social status or prestige, Kopatz/Pilz cite various authors, who mention as a reason for this negative perception the fact that in Canada, vocational training is perceived as an option for young people with social or personal problems or, more generally, for those with learning difficulties [23; 15;24; 25], while academic qualifications are perceived as underpinning social standing. Therefrom the conclusion derives that social status seems to be the most significant contributory factor to vocational training's low status in Canada. As already mentioned above the German literature suggests that besides the higher prestige also a higher wage classification as well as the access to a broader set of follow-up programmes are central criteria for choosing an academic qualification instead of an apprenticeship $[1 ; 2 ; 3]$.

\section{Conclusion}

For Germany as well as for Canada the above results show that obtaining an academic degree does not necessarily generate a higher return to investment than completing vocational training. As Kopatz/Pilz (2015) state this shows empirically that Becker's classic "human capital" theory does not apply a priori [8: 321$]$. Due to the available data the presented results are more differentiated and include a broader variety of occupational fields for Germany. Here a higher return to investment for further vocational training in comparison to initial vocational training can be determined. Interestingly in Germany especially the holders of a Bachelor's degree do not obtain higher earnings than vocationally qualified persons. Here the phenomenon occurs that within certain occupational fields bachelor graduates earn even less than those holding a vocational qualification.

Comparing our results to the findings of Kopatz/Pilz for the Canadian case it becomes apparent that the differentials in Germany are smaller, especially for Bachelor's degrees. This might be due to still relatively few employees with these degrees on the labour market and hence employers only having little experience with bachelor's degrees expected work capabilities. Although the results for Canada derive from a smaller sample of compared occupations, they also clearly show that vocational training can offer equally high monetary returns as academic qualifications.

Furthermore the comparative analysis documents that definitely in Canada and in Germany more and more young people tend to choose the "academic route" instead of the "vocational route" as the respective qualifications are associated with a higher social status/prestige, neglecting the comparable monetary outcomes of both choices. So the underlying decision calculus of young people in both countries can be perceived as comparable. An in depth evaluation of the de facto usability of academic and vocational qualifications in Germany is the key question of the research project. At the moment we are preparing the analysis of various curricula to gain more information about the profiles and the contents of the respective qualifications.

\section{References}

[1] Baethge, M./Kerst, C./Leszczensky, M./Wieck, M.: Zur neuen Konstellation zwischen Hochschulbildung und Berufsausbildung. HIS: Forum Hochschule 3/2014. Hannover 2014.

[2] Dobischat, R./ Fischell, M./Rosendahl, A.: Auswirkungen der Studienreform durch die Einführung des Bachelorabschlusses auf das Berufsbildungssystem Eine Problemskizze. Düsseldorf 2008.

[3] Severing, E./Teichler, U.: Akademisierung der Berufswelt? Verberuflichung der Hochschulen? In: Severing, E./Teichler, U. (Hrsg.): Akademisierung der Berufswelt? Bielefeld 2013, S. 7-18.

[4] Weiß, R.: Bachelor Professional - ein Beitrag zur Aufwertung der beruflichen Bildung? In: BWP 4/2007, S. 47-50.

[5] Briedis, K./Heine, C./Konegen-Grenier, C./Schröder, A.-K.: Mit dem Bachelor in den Beruf. Arbeitsmarktbefähigung und -akzeptanz von Bachelorstudierenden und -absolventen. Essen 2011.

[6] DIHK: Kompetent und praxisnah -Erwartungen der Wirtschaft an Hochschulabsolventen. Ergebnisse einer DIHK Online-Unternehmensbefragung. Berlin 2015.

DIHK: Erwartungen der Wirtschaft an Hochschulabsolventen. Berlin 2011.

[7] Konegen-Grenier, C./Placke, B./Schröder-Kralemann, A.-K.: Karrierewege für Bachelorabsolventen Ergebnisbericht zur Unternehmensbefragung 2014. Stifterverband für die Deutsche Wissenschaft (Hrsg.), Analysen, Essen 2015.

[8] Kopatz, S./Pilz, M.: The Academic Takes it All? A Comparison of Returns to Investment in Education between Graduates and Apprentices in Canada. In: International Journal for Research in Vocational Education and Training, Volume 2, No. 4, 2015, p. 308325 .

[9] Boothby, D./Drewes, T.: Postsecondary Education in Canada: Returns to University, College and Trades Education. Canadian Public Policy/Analyse de Politiques, 32(1), 1-21. 2006.

[10] Cohn, E./Addison, J. T.: The Economic Returns to Lifelong Learning in OECD Countries. Education Economics, 6 (3), 253-307. 1998. 
[11] Spence, M.: "Job Market Signaling", in The Quarterly Journal of Economics, vol. 87, no. 3, 1973, pp. 355-374.

[12] Sengenberger, W.: Struktur und Funktionsweise von Arbeitsmärkten, Frankfurt/New York: campus, 1987.

[13] Doeringer, P. B./Piore, M. J.: Internal Labour Markets and Manpower Analysis. Lexington, Mass.: Routledge, 1971.

[14] Rohrbach-Schmidt, D./Hall, A.: "BIBB/BAua Employment Survey 2012", BIBB-FDZ Data and Methodological Reports Nr. 1/2013, Federal Institute for Vocational Education and Training, Research Data Center, Bonn, 2013.

[15] Tiemann M./Schade, H.J./Helmrich, R. /Hall A. / Braun, U. /Bott, P.: Berufsfeld-Definitionen des BIBB auf Basis der KldB 1992. Wdp 105, Bonn 2008.

[16] Psacharopoulos, G./NG, Y. C.: Earnings and Education in Latin America. In: Education Economics, 2(2), 1994, p. 187-207.

[17] Bayard, J./Greenlee, E.: Graduating in Canada: Profile, Labour Market Outcomes and Student Debt of the Class of 2005. Research Paper Statistics Canada, No. 074, 2009.

[18] Tamborini, C. R/Kim, C. H./Sakamoto, A.: Education and Lifetime Earnings in the United States, Demography, vol. 52, 2015, pp. 1383-1407

[19] Jeong, H./Kim Y./Manovskii, I.: The Price of Experience, American Economic Review, vol. 105, nr. 2, 2015, pp. $784-815$

[20] Molgat, M., Deschenaux, F./LeBlanc, P.: Vocational education in Canada: do policy directions and youth trajectories always meet?. Journal of Vocational Education and Training, 63(4), 505-524. 2011.

[21] Bundesinstitut für Berufsbildung (BIBB): Datenreport zum Berufsbildungsbericht 2015 Informationen und Analysen zur Entwicklung der beruflichen Bildung, Bonn 2015.

[22] Dionisius, R./Illiger, A.: Mehr Anfänger/-innen im Studium als in Berufsausbildung? In: BWP 4/2015, p. 4345.

[23] Lehmann, W.: 'For some reason, I get a little scared': structure, agency and risk in school-work transitions. Journal of Youth Studies, 7(4), 379-396. 2004.

[24] Taylor, A.: The Challenges of Partnership in Schoolto-work Transition. Journal of Vocational Education and Training, 58(3), 319-336. 2006.

[25] Taylor, A.: 'You have to have that in your nature: understanding the trajectories of youth apprentices. Journal of Youth Studies, 1(4), 393-411. 2008. 